\title{
Safety comparison of additives in antiglaucoma prostaglandin (PG) analog ophthalmic formulations
}

This article was published in the following Dove Press journal:

Clinical Ophthalmology

II March 2013

Number of times this article has been viewed

\section{Masamichi Fukuda \\ Shinsuke Shibata \\ Naoko Shibata \\ Kenta Hagihara \\ Hiromoto Yaguchi \\ Hiromi Osada \\ Nobuo Takahashi \\ Eri Kubo \\ Hiroshi Sasaki}

Department of Ophthalmology, Kanazawa Medical University,

Uchinada, Japan
Correspondence: Masamichi Fukuda Department of Ophthalmology, Kanazawa Medical University, I-I Daigaku, Uchinada-machi, Kahoku-gun Ishikawa, 920-0293, Japan

Tel +81762862211 ext 3417

Fax +81762861010

Email fukuda@kanazawa-med.ac.jp
Purpose: To investigate the safety of five types of antiglaucoma prostaglandin analog ophthalmic formulations, and to clarify their differences in accordance with contained additives (preservatives and surface-active agents).

Methods: The following five types of ophthalmic solutions and three types of additives were investigated: latanoprost (Xalatan ${ }^{\circledR}$; latanoprost), tafluprost (Tapros ${ }^{\circledR}$; tafluprost), bimatoprost (Lumigan $^{\circledR}$; bimatoprost), travoprost (Travatan ${ }^{\circledR}$; travoprost), travoprost (Travatan $Z^{\circledR}$; travoprost$\mathrm{Z}$ ), benzalkonium chloride (BAK), polyoxyethylene hardening castor oil 40 (HCO-40), and polysorbate 80 (P-80). These experimental solutions were exposed to the cultured cells of a rabbit-derived corneal cell line for a certain time, and the exposure time causing $50 \%$ cell damage (CD50), indicated by the ratio of viable cells to total cells was calculated (in vitro). In addition, corneal resistance $(\mathrm{CR})$ was measured and $\mathrm{CR}$ ratio (post-treatment $\mathrm{CR} /$ pretreatment $\mathrm{CR} \times 100$ ) was calculated (in vivo).

Results: CD50 of each ophthalmic solution was the longest with tafluprost, followed by travoprost-Z, bimatoprost, travoprost, and latanoprost. CD50 of $0.005 \%, 0.01 \%$, and $0.02 \%$ BAK was 14.5 minutes, 8.1 minutes, and 4.0 minutes, respectively. The number of viable cells decreased to $60 \%, 8$ minutes after exposure with HCO-40, and 30 minutes after being exposed to $\mathrm{P}-80$. The CR ratio was $81.0 \%$ with travoprost and $82.0 \%$ with latanoprost, indicating a significant posttreatment reduction of $\mathrm{CR}(P<0.05)$. The $\mathrm{CR}$ ratio did not decrease after treatment with tafluprost, travoprost-Z, or bimatoprost. The CR ratio of $0.005 \%, 0.01 \%$, and $0.02 \%$ BAK was $105.0 \%, 90.5 \%$, and $68.7 \%$, respectively, and that of HCO-40 and P-80 was $108.7 \%$ and $114.2 \%$, respectively.

Conclusion: BAK, HCO-40, and P-80 were thought to be involved in corneal injuries caused by each ophthalmic solution. Corneal injuries due to surface action were observed when using HCO-40 and P-80. When HCO-40 was combined with BAK, it induced micellar BAK and reduced corneal injuries by BAK.

Keywords: corneal resistance measuring device, additives, prostaglandin analogs, surface-active agents, corneal epithelial injury

\section{Introduction}

The existing prostaglandin (PG) analogs, including latanoprost, are prodrugs whose carboxyl end is esterified, and classified as PGF2 $\alpha$ derivatives. All these drugs are reported to be transformed to active acid forms through metabolism by esterase on corneal penetration and bind to prostanoid (PGF receptor); which results in an aqueous outflow promoting effect. ${ }^{1}$ The treatments for glaucoma and ocular hypertension have recently centered on lowering intraocular pressure (IOP) regardless of disease types, and PG analogs that have strong IOP lowering effects 
and excellent systemic safety are frequently used as first choice drugs. Recently in Japan, there have been many medicinal options for glaucoma since five types of PGF $2 \alpha$ derivatives, three types of combination preparations, and 23 generic drugs of $0.005 \%$ latanoprost ophthalmic solution (Xalatan ${ }^{\circledR}$ ophthalmic solution, Pfizer, Inc, New York, NY, USA) have been launched.

The harmful effect of preservatives of latanoprost ophthalmic solution on the corneal epithelium has been acknowledged as a clinical problem. We have investigated the safety of various ophthalmic solutions against the corneal epithelial cells using rabbit cultured corneal cells (in vitro) and with a corneal resistance (CR) measuring device (in vivo). ${ }^{2-5}$ In this study, using five types of PG analogs, as well as in vitro and in vivo experimental systems, we investigated the influence of both active and inactive ingredients of each solution (including surface-active agents and preservatives) on the corneal epithelium.

\section{Methods}

\section{Materials}

\section{Experimental solutions and additives}

The following ophthalmic solutions and additives were used. Their active and inactive ingredients are shown in Table 1.

- Latanoprost ophthalmic solution $0.005 \%$ (Xalatan ${ }^{\circledR}$, Pfizer Inc, New York, NY, USA) with an active ingredient of latanoprost (PGF2 $\alpha$ derivative) (hereafter latanoprost);

- Tafluprost ophthalmic solution $0.0015 \%$ (Tapros $^{\circledR}$, Santen Pharmaceutical Co, Ltd, Osaka, Japan) with tafluprost (PGF2 $\alpha$ derivative) (hereafter tafluprost);

- Bimatoprost ophthalmic solution $0.03 \%$ (Lumigan $^{\circledR}$, Senju Pharmaceutical Co, Ltd, Osaka, Japan) with bimatoprost (prostamide derivative) (hereafter bimatoprost);
- Travoprost ophthalmic solution $0.004 \%$ (Travatan ${ }^{\circledR}$, Alcon Laboratories, Inc, Fort Worth, TX, USA) with travoprost (PGF2 $\alpha$ derivative) (hereafter travoprost);

- Travoprost ophthalmic solution $0.004 \%$ (Travatan $Z^{\circledR}$, Alcon Laboratories, Inc, Fort Worth, TX, USA) with travoprost (PGF2 $\alpha$ derivative) (hereafter travoprost-Z);

- Benzalkonium chloride (BAK) $(0.005 \%, 0.01 \%, 0.02 \%)$ (Tokyo Chemical Industry Co, Ltd, Tokyo, Japan);

- Polyoxyethylene hardened castor oil 40 (hereafter HCO-40) (0.1\%) (Itoh Oil Chemicals Co, Ltd, Mie, Japan); and

- Polysorbate 80 (P-80) (0.1\%) (Wako Pure Chemical Industries, Ltd, Osaka, Japan).

\section{Animals}

Twenty adult male New Zealand white rabbits (body weight: $3.0-3.5 \mathrm{~kg}$ ) were used.

\section{Cultured cells}

Cultured rabbit-derived corneal cell lines (Statens Seruminstitut Rabbit Cornea (SIRC); American Type Culture Collection CCL60, Manassas, VA, USA) were used. The cells were cultured with Dulbecco's Modified Eagle's (DME) Medium containing $10 \%$ fetal bovine serum and incubated with $5 \%$ $\mathrm{CO}_{2}$ at $37^{\circ} \mathrm{C}$.

\section{Corneal resistance measuring device}

A bipolar corneal contact lens carrying two concentric gold wire electrodes (Mayo Corporation, Aichi, Japan) was used to measure the CR. The gold wire electrodes were fixed to the inner surface of the corneal contact lens, and the electrodes delivered the electrical pulses and recorded the voltage drop across the cornea. $\mathrm{CR}(\Omega)$ was calculated using the following equation:

$$
\mathrm{CR}(\Omega)=\text { voltage }(\mathrm{V}) / \operatorname{current}(\mathrm{A})
$$

Table I Composition of five types of antiglaucoma PG analog ophthalmic formulations

\begin{tabular}{|c|c|c|c|c|c|}
\hline $\begin{array}{l}\text { Opthalmic } \\
\text { solution }\end{array}$ & $\begin{array}{l}\text { Xalatan }^{\circledR} \\
\text { ophthalmic } \\
\text { solution } 0.005 \%\end{array}$ & $\begin{array}{l}\text { Tapros }^{\circledR} \\
\text { ophthalmic } \\
\text { solution } 0.0015 \%\end{array}$ & $\begin{array}{l}\text { Lumigan }^{\circledR} \\
\text { ophthalmic } \\
\text { solution } 0.03 \%\end{array}$ & $\begin{array}{l}\text { Travatan }^{\circledR} \\
\text { ophthalmic } \\
\text { solution } 0.004 \%\end{array}$ & $\begin{array}{l}\text { Travatan- } Z^{\circledR} \\
\text { ophthalmic } \\
\text { solution } 0.004 \%\end{array}$ \\
\hline $\begin{array}{l}\text { Active } \\
\text { ingredient }\end{array}$ & Latanoprost $50 \mu \mathrm{g} / \mathrm{mL}$ & Tafluprost $15 \mu \mathrm{g} / \mathrm{mL}$ & Bimatoprost $0.3 \mathrm{mg} / \mathrm{mL}$ & Travoprost $40 \mu g / \mathrm{mL}$ & Travoprost $40 \mu \mathrm{g} / \mathrm{mL}$ \\
\hline Additives & $\begin{array}{l}\text { Benzalkonium chloride } \\
(0.02 \%), \text { hydrogen } \\
\text { phosphate sodium, } \\
\text { sodium dihydrogen- } \\
\text { phosphate, tonicity } \\
\text { adjusting agents }\end{array}$ & $\begin{array}{l}\text { Benzalkonium chloride } \\
(0.001 \%), \text { sodium } \\
\text { dihydrogen-phosphate } \\
\text { hydrate, EDTA, strong } \\
\text { glycerin, polysorbate } 80 \text {, } \\
\mathrm{pH} \text { regulator }\end{array}$ & $\begin{array}{l}\text { Benzalkonium chloride } \\
(0.005 \%), \text { hydrogen } \\
\text { phosphate sodium } \\
\text { hydrate, sodium chloride, } \\
\text { citric acid hydrate, } \\
\text { hydrochloric acid, } \\
\text { sodium hydroxide }\end{array}$ & $\begin{array}{l}\text { Benzalkonium } \\
\text { chloride }(0.015 \%) \text {, } \\
\text { polyoxyethylene } \\
\text { hydrogenated castor } \\
\text { oil } 40 \text {, trometamol, } \\
\text { boric acid, mannitol, } \\
\text { pH regulator, EDTA }\end{array}$ & $\begin{array}{l}\text { Polyoxyethylene } \\
\text { hydrogenated castor } \\
\text { oil 40, propylene } \\
\text { glycol, boric acid, } \\
\text { D-sorbitol, zinc } \\
\text { chloride, pH } \\
\text { regulator }\end{array}$ \\
\hline
\end{tabular}

Abbreviations: PG, prostaglandin; EDTA, ethylenediaminetetraacetic acid. 
The resistance of the tissue can be calculated by Ohm's Law: resistance $(\Omega)$ is equal to the voltage $(\mathrm{V})$ divided by the current (I in amperes).

\section{Experimental methods}

Evaluation using cultured cells of rabbit-derived corneal cells (in vitro)

SIRC cells $\left(2 \times 10^{5}\right)$ were cultured in DME media with $10 \%$ fetal bovine serum and incubated for 5 days. The cells were exposed to each ophthalmic solution and three types of surface-active agents $(200 \mu \mathrm{L})$ for 0-60 minutes, and the number of cells were counted by Coulter counter method. The number of cells that were not exposed to the drug was regarded as 100, and the cell survival rate (\%) was calculated. Then the exposure time causing 50\% cell damage (hereafter CD50) for each ophthalmic solution was calculated. CD50 (minutes) was obtained from the following quadratic formula based on the survival rate (\%):

$$
\mathrm{aX}+\mathrm{bX}+\mathrm{c}=0(\neq 0), \mathrm{X}=-\mathrm{b} \pm \sqrt{b^{2}-4 a c / 2 a} \text {. }
$$

\section{Evaluation using a corneal resistance measuring device (in vivo)}

Latanoprost, tafluprost, bimatoprost, travoprost, travoprostZ, BAK $(0.005 \%, 0.01 \%, 0.02 \%)$, HCO- 40 , or P-80 was instilled into the conjunctival sac of mature white rabbits three times at 15 -minute intervals $(50 \mu \mathrm{L}$ each time $)$, and $\mathrm{CR}$ was measured at 2 minutes, 30 minutes and 60 minutes after instillation was completed. The rabbits were divided into seven groups, and each group included four eyes. CR was measured using a CR measuring device, and $\mathrm{CR}$ value $(\Omega)$ and $\mathrm{CR}$ ratio (\%) were calculated as follows:

$$
\mathrm{CR}(\Omega)=\text { voltage }(\mathrm{V}) / \text { current }(\mathrm{A})
$$

$$
\begin{gathered}
\mathrm{CR} \text { ratio }(\%)=\mathrm{CR} \text { after instillation } / \mathrm{CR} \times 100 \\
\text { before instillation }
\end{gathered}
$$

\section{Evaluation of corneal injury by fluorescein staining} Corneal epithelial injury caused by each ophthalmic solution or surface-active agent was observed under a slit-lamp microscope by instilling $2 \mu \mathrm{L}$ of $1 \%$ fluorescein sodium to the conjunctival sac 2 minutes, 30 minutes, and 60 minutes after instillation completion. The staining intensities were evaluated according to area density (AD) classification. ${ }^{6}$

\section{Statistical analysis}

Results of corneal injury (in vitro) and that using a CR measurement (in vivo) were obtained from at least four experiments. Student's $t$-test was used for statistical analysis, and $P$-values of not less than 0.05 were considered to be statistically significant.

\section{Results \\ Evaluation using cultured cells of rabbit- derived corneal cells (in vitro)}

The cell survival rate with latanoprost decreased with longer exposure times, and significantly decreased 60 minutes after exposure. The cell survival rate with travoprost was almost the same as that with travoprost- $Z$ until 30 minutes after exposure (60\%), but significantly became lower 60 minutes after exposure. The cell survival rate with tafluprost was kept at approximately $80 \%$. On the other hand, the cell survival rate with bimatoprost decreased in a time-dependent manner. CD50 of each ophthalmic solution was the longest with tafluprost, followed by travoprost-Z, bimatoprost, travoprost, and latanoprost (Figure 1). CD50 of $0.005 \%, 0.01 \%$, and $0.02 \%$ BAK was 14.5 minutes, 8.1 minutes, and 4.0 minutes, respectively (Figure 2). The cell survival rate with $\mathrm{HCO}-40$ $(0.1 \%)$ decreased to $60 \%$, and that of P-80 $(0.1 \%)$ decreased to $80 \%$ until 8 minutes after exposure, which indicated a difference in speed decreases between them (Figure 3). Cell injuries were the most severe with BAK, followed by HCO40 and P-80 (Table 2).

\section{Evaluation using a corneal resistance measuring device (in vivo)}

CR ratio (\%) significantly decreased with latanoprost $(82.0 \%, 2$ minutes after instillation) and with travoprost (81.0\%, 30 minutes after instillation), but recovered as time

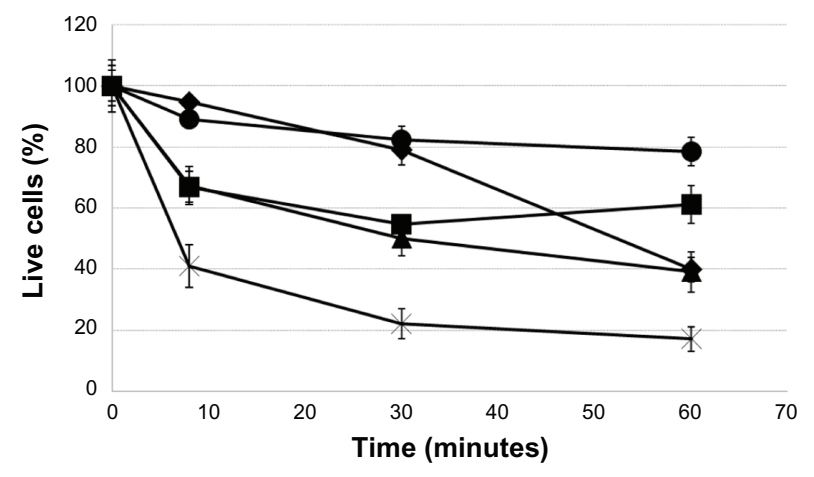

Figure I Evaluation of five types of antiglaucoma PG analog ophthalmic formulations using cultured cells of a rabbit-derived corneal cell line (in vitro).

Notes: $\boldsymbol{\Delta}$ : latanoprost; $\bullet$ : tafluprost; $\times$ : bimatoprost; $\square$ : travoprost; $\mathbf{\square}$ : travoprost-Z. The CD50 of each ophthalmic solution was the longest with tafluprost, followed by travoprost-Z, bimatoprost, travoprost, and latanoprost.

Abbreviations: CD50, exposure time causing 50\% cell damage; PG, prostaglandin. 


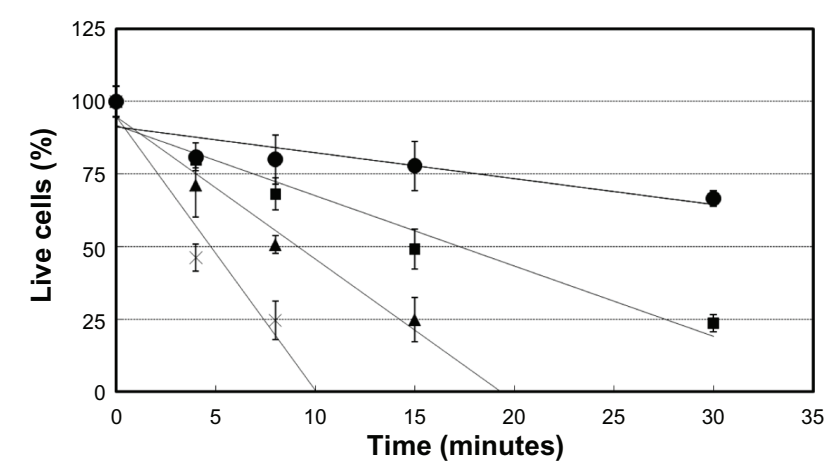

Figure 2 Evaluation of BAK using cultured cells of a rabbit-derived corneal cell line (in vitro).

Notes: $\bullet: 0.0025 \%$ BAK; $\mathbf{\square}: 0.005 \%$ BAK; $\mathbf{\Delta}: 0.01 \%$ BAK; $\times$ : $0.02 \%$ BAK. CD50 of $0.005 \%, 0.01 \%$, and $0.02 \%$ BAK was 14.5 minutes, 8.1 minutes, and 4.0 minutes, respectively.

Abbreviations: BAK, benzalkonium chloride; CD50, exposure time causing $50 \%$ cell damage.

advanced $(P<0.05)$. On the other hand, a decrease in the $\mathrm{CR}$ ratio was rarely observed with travoprost-Z. The CR ratio with tafluprost or bimatoprost did not decrease, and tended to be slightly higher after instillation (Figure 4). The ratio was $105.0 \%$ with $0.005 \% \mathrm{BAK}, 90.5 \%$ with $0.01 \%$ BAK, $68.7 \%$ with $0.02 \%$ BAK, $108.7 \%$ with HCO-40, and $114.2 \%$ with P-80. The cell injuries due to each active and inactive ingredient were identified in vivo (Table 2).

\section{Evaluation of corneal injury by fluorescein staining (in vivo)}

According to AD classification using fluorescein staining, corneal injury was A1D1 with travoprost (30 minutes after instillation; four out of four eyes), and A1D2 with latanoprost

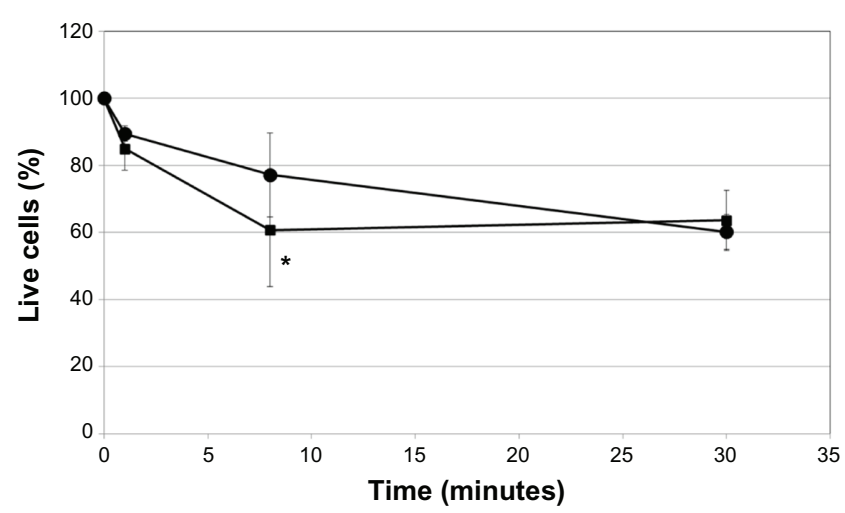

Figure 3 Evaluation of surface-active agents ( $\mathrm{HCO}-40$ and P-80) using cultured cells of a rabbit-derived corneal cell line (in vitro).

Notes: $\mathbf{m}$ : HCO-40 (0.1\%); •: P-80 (0.1\%); *P $<0.05$. The cell survival rate with HCO-40 (0.1\%) decreased to $60 \%$, and that of P-80 (0.1\%) decreased to $80 \%$ until 8 minutes after exposure, which indicated a difference in the decreasing speed between them.

Abbreviations: HCO-40, polyoxyethylene hardening castor oil 40; P-80, polysorbate 80 .
Table 2 CD50 (minutes), CR ratio (\%), and the relation to $A D$ classification of each ophthalmic solution and additive

\begin{tabular}{|c|c|c|c|}
\hline Ophthalmic solution & $\begin{array}{l}\text { CR } \\
\text { (\%) }\end{array}$ & $\begin{array}{l}\text { CDT50 } \\
\text { (minutes) }\end{array}$ & $\begin{array}{l}\text { AD } \\
\text { classification }\end{array}$ \\
\hline Latanoprost (Xalatan $\left.{ }^{\circledast}\right)$ & 82.0 & 11.6 & AID2 \\
\hline Tafluprost (Tapros ${ }^{\circledR}$ ) & 113.2 & $>60$ & A0D0 \\
\hline Bimatoprost (Lumigan ${ }^{\circledR}$ ) & 118.0 & 50.5 & AODO \\
\hline Travoprost (Travatan $\left.{ }^{\circledR}\right)$ & 81.0 & 25.3 & AIDI \\
\hline Travoprost (Travatan $\left.Z^{\circledR}\right)$ & 96.6 & 51.0 & AOD0 \\
\hline BAK $(0.005 \%)$ & 105.0 & 14.5 & A0D0 \\
\hline BAK $(0.01 \%)$ & 90.5 & 8.1 & AIDI \\
\hline BAK $(0.02 \%)$ & 68.7 & 4.0 & A2D2 \\
\hline $\mathrm{HCO}-40(0.1 \%)$ & 108.7 & 24.6 & AODO \\
\hline $\mathrm{P}-80(0.1 \%)$ & I 14.2 & 37.2 & AOD0 \\
\hline
\end{tabular}

Notes: Cell injuries were the most severe with BAK, followed by P- 80 and HCO- 40 . The CR ratio (\%) significantly decreased with latanoprost (82.0\%, 2 minutes after instillation) and with travoprost (8I.0\%, 30 minutes after instillation), but recovered as time advanced $(P<0.05)$. On the other hand, a decrease in the CR ratio was rarely observed with travoprost-Z. The CR ratio with tafluprost or bimatoprost did not decrease, and tended to be slightly higher after instillation.

Abbreviations: CD50, exposure time causing $50 \%$ cell damage; $C R$, corneal resistance; $A D$, area density; $B A K$, benzalkonium chloride; $\mathrm{P}-80$, polysorbate 80 ; HCO-40, polyoxyethylene hardening castor oil 40.

(2 minutes after instillation; four out of four eyes). On the other hand, the injury was A0D0 with travoprost-Z, bimatoprost, and tafluprost at each time point (four out of four eyes). Corneal injury was A0D0 with $0.005 \%$ BAK, A1D1 with $0.01 \%$ BAK, A2D2 with $0.02 \%$ BAK, A0D0 with HCO-40, and A0D0 with P-80 (Table 2).

\section{Discussion}

The effects of five PGs on the corneal epithelium were evaluated by in vitro and in vivo experimental models, and the influences of each ophthalmic solution and its additives, such as surfactant and preservatives on the corneal epithelium, were investigated.

Corneal epithelium disorder caused by BAK, the additive of PGF $2 \alpha$, is considered to be a safety issue clinically, and this is well known. ${ }^{7,8}$

These medications contain the preservative BAK, which has been shown to be primarily responsible for the allergic, inflammatory, and cytotoxic epithelial reactions associated with long-term use of these IOP-lowering medications. ${ }^{9-12}$ Long-term exposure to BAK causes toxicity, which is seen as inflammation of the ocular surface with epithelial cell damage, decreased tear production, tear film instability, increased corneal epithelial permeability, and cellular apoptosis..$^{10,13-15}$

The BAK concentrations of five PG ophthalmic solutions investigated in this study were: travoprost-Z, $0 \%$; tafluprost, $0.001 \%$; bimatoprost, $0.005 \%$; travoprost, $0.015 \%$; and latanoprost, $0.02 \%$. 


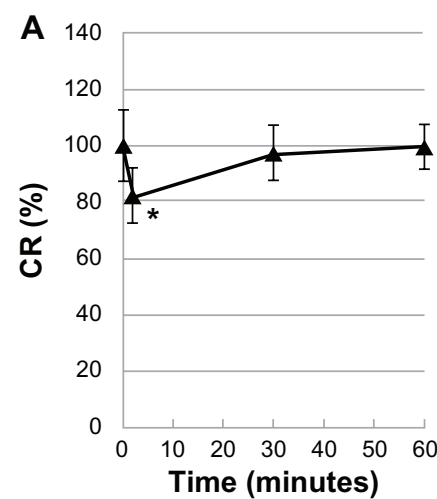

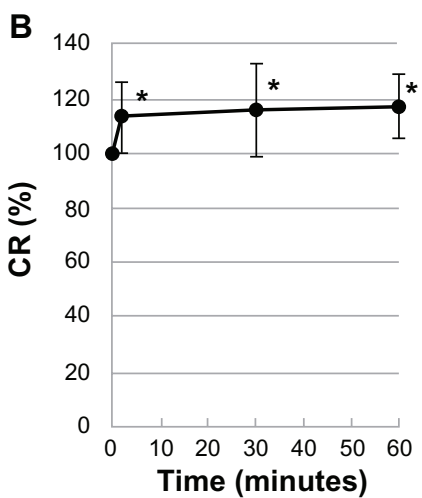

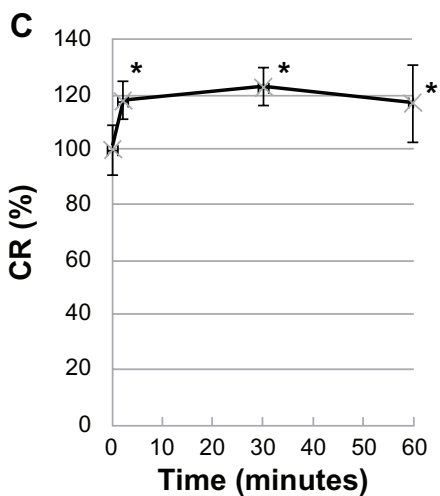

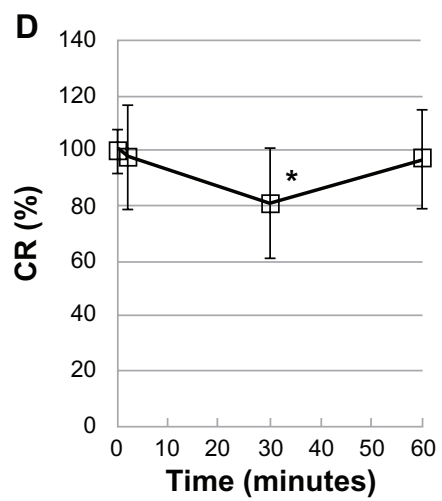

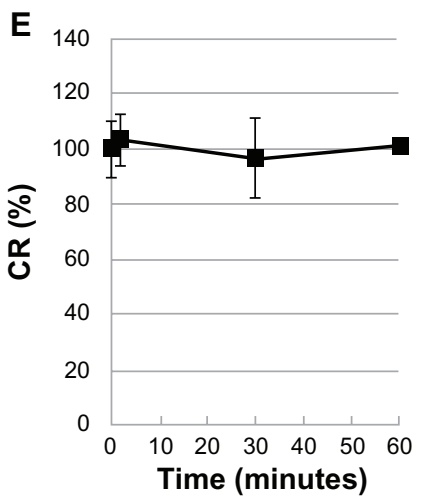

Figure 4 Evaluation of five types of antiglaucoma PG analog ophthalmic formulations using corneal resistance measuring device (in vivo).

Notes: (A) $\Delta$ : latanoprost; (B) $\bullet$ : tafluprost; (C) $\times$ : bimatoprost; (D) $\square$ : travoprost; (E) $\mathbf{\square}$ : travoprost-Z; $* P<0.05 ; N=4$, (mean $\pm S D$ ). CR ratio (\%) significantly decreased with latanoprost (82.0\%, 2 minutes after instillation) and with travoprost (81.0\%, 30 minutes after instillation), but recovered as time advanced $(P<0.05)$. On the other hand, a decrease in the CR ratio was rarely observed with travoprost-Z. The CR ratio with tafluprost or bimatoprost did not decrease, and tended to be slightly higher after instillation. Abbreviations: PG, prostaglandin; CR, corneal resistance; SD, standard deviation.

Travoprost-Z is formulated with SofZia8, the zinc chloride preservative, instead of BAK. As shown in Table 1, all five ophthalmic solutions had different combinations of preservatives and surfactants, each with unique concentrations and the different types of additives. Therefore, the combinations may be of interest when evaluating the effects of additives on the corneal epithelium.

The degrees of corneal damage by in vitro evaluation by cultured rabbit corneal cells as determined by the CD50 of each ophthalmic solution were tafluprost $>$ travoprost-Z $>$ bimatoprost $>$ travoprost $>$ latanoprost. This is roughly dependent on the BAK concentrations of each drug. This result is in clear agreement with the previous reports on BAK. ${ }^{5}$ The effect of $0.1 \%$ HCO- 40 and $0.1 \%$ P- 80 were considered to be the cause of corneal damage other than by BAK. Thus, the evaluation of cultured rabbit corneal cells is considered highly useful to elucidate the mechanism of cellular toxicity, which is the basic characteristic of the ophthalmic solutions, and which is involved in the investigation into the possible causal factor of toxicity. However, it is a difficult task to evaluate the clinical safety of each ophthalmic solution.
Therefore, the authors developed an apparatus to measure the CR as a method to evaluate corneal damage by the ophthalmic solution; the resulting damage was similar to clinical conditions. By this method, the $\mathrm{CR}(\%)$ of latanoprost with $0.02 \%$ BAK and travoprost with $0.015 \%$ BAK were significantly reduced to $82.0 \%$ and $81.0 \%$, respectively (both $P<0.05)$, and recovered with time afterwards. On the other hand, travoprost- $Z$ without BAK reported almost no decrease throughout the measured time points.

Results were similar for tafluprost and bimatoprost, and CR (\%) was not decreased. Similarly to the results from the cultured rabbit corneal cell model, the degree of corneal damage that occurred was considered to be dependent on the BAK concentration in the ophthalmic solutions.

The advantage of evaluating the CR measurement by our apparatus is that its results reflect the actual phenomena occurring in the living eyes, and the results show the realtime quantitative measurements of the course of corneal damage and the process of recovery from the damage. This is the most significant difference from the in vitro investigation. We consider this apparatus highly useful as one of the 
diagnostic tools used on the cornea from the aspect of clinical applications, and it can also be used as a method of evaluation for the development of drug formulations.

This study was able to reconfirm that five PG drugs have differences in their effects on the cornea. Despite this fact, we think even the BAK-added ophthalmic solutions are still considered safe to the normal cornea when administered as a single agent, and in one instillation daily. However, for the patients whose corneas are sensitive, or who need concomitant glaucoma drugs, it is preferable to select ophthalmic solutions that result in the minimum amount of insult to the cornea.

In conclusion, there were correlations between the evaluations from in vitro and in vivo methods, and the degree of corneal damage was in the order of: latanoprost $>$ travoprost $>$ bimatoprost $\geq$ travoprost- $Z>$ tafluprost. On the other hand, the major causes of corneal damage were considered to be the involvement of BAK and HCO-40; however, HCO-40, a surfactant that creates micelle-wrapped BAK, has been suggested to reduce the damaging effect of BAK. ${ }^{16}$

\section{Conclusion}

There was a correlation between in vitro and in vivo results, and the corneal injury was the most severe with latanoprost, and the most mild with tafluprost (latanoprost $>$ travoprost $>$ bimatoprost $\geq$ travoprost- $Z>$ tafluprost). BAK and $\mathrm{HCO}-40$ were thought to be involved in corneal injuries. When HCO40 was combined with BAK, it induced micellar BAK and reduced corneal injuries.

\section{Disclosure}

The authors report no conflicts of interest in this work.

\section{References}

1. Bito LZ. Comparison of the ocular hypotensive efficacy of eicosanoids and related compounds. Exp Eye Res. 1984;38(2):181-194.

2. Fukuda M, Sasaki H. Quantitative evaluation of corneal epithelial injury caused by n-heptanol using a corneal resistance measuring device in vivo. Clin Ophthalmol. 2012;6:585-593.
3. Fukuda M, Sasaki H. [Cytotoxic effect of ofloxacin ophthalmic solutions and timolol maleate ophthalmic solutions on cultured rabbit corneal cell line and ocular pharmacokinetics of ophthalmic solutions in rabbits]. Atarashii Ganka (Journal of the Eye). 2009;26(7):977-981. Japanese.

4. Fukuda M, Sasaki H. [Cytotoxic effects of new quinolone antibiotic ophthalmic solutions and nonsteroidal anti-inflammatory ophthalmic solutions on cultured rabbit corneal cell line]. Atarashii Ganka (Journal of the Eye). 2009;26(3):399-403. Japanese.

5. Fukuda M, Yamamoto K, Takahashi N, Sasaki H, Yoshikawa M. [Corneal disorder quantification by corneal resistance]. Atarashii Ganka (Journal of the Eye). 2007;24(4):521-525. Japanese.

6. Miyata K, Amano S, Sawa M, Nishida T. A novel grading method for superficial punctate keratopathy magnitude and its correlation with corneal epithelial permeability. Arch Ophthalmol. 2003;121(11): $1537-1539$.

7. Baudouin C. Detrimental effect of preservatives in eyedrops: implications for the treatment of glaucoma. Acta Ophthalmol. 2008;86(7): 716-726.

8. Kahook MY, Noecker RJ. Comparison of corneal and conjunctival changes after dosing of travoprost preserved with sofZia, latanoprost with $0.02 \%$ benzalkonium chloride, and preservative-free artificial tears. Cornea. 2008;27(3):339-343.

9. Guenoun JM, Baudouin C, Rat P, Pauly A, Warnet JM, BrignoleBaudouin F. In vitro study of inflammatory potential and toxicity profile of latanoprost, travoprost, and bimatoprost in conjunctiva-derived epithelial cells. Invest Ophthalmol Vis Sci. 2005;46(7):2444-2450.

10. Kuppens EV, de Jong CA, Stolwijk TR, de Keizer RJ, van Best JA. Effect of timolol with and without preservative on the basal tear turnover in glaucoma. Br J Ophthalmol. 1995;79(4):339-342.

11. Fisher AA. Allergic contact dermatitis and conjunctivitis from benzalkonium chloride. Cutis. 1987;39(5):381-383.

12. Baudouin C. Allergic reaction to topical eyedrops. Curr Opin Allergy Clin Immunol. 2005;5(5):459-463.

13. De Saint Jean M, Debbasch C, Brignole F, Rat P, Warnet JM, Baudouin C. Toxicity of preserved and unpreserved antiglaucoma topical drugs in an in vitro model of conjunctival cells. Curr Eye Res. 2000;20(2): 85-94.

14. Göbbels M, Spitznas M. Corneal epithelial permeability of dry eyes before and after treatment with artificial tears. Ophthalmology. 1992; 99(6):873-878.

15. Baudouin C, de Lunardo C. Short-term comparative study of topical $2 \%$ carteolol with and without benzalkonium chloride in healthy volunteers. Br J Ophthalmol. 1998;82(1):39-42.

16. Jin X, Streett DA, Dunlap CA, Lyn ME. Application of hydrophilic-lipophilic balance (HLB) number to optimize a compatible non-ionic surfactant for dried aerial conidia of Beauveria bassiana. Biological Control: Theory and Application in Pest Management. 2008;46(2):226-233.
Clinical Ophthalmology

\section{Publish your work in this journal}

Clinical Ophthalmology is an international, peer-reviewed journal covering all subspecialties within ophthalmology. Key topics include: Optometry; Visual science; Pharmacology and drug therapy in eye diseases; Basic Sciences; Primary and Secondary eye care; Patient Safety and Quality of Care Improvements. This journal is indexed on Submit your manuscript here: http://www.dovepress.com/clinical-ophthalmology-journal

\section{Dovepress}

PubMed Central and CAS, and is the official journal of The Society of Clinical Ophthalmology (SCO). The manuscript management system is completely online and includes a very quick and fair peer-review system, which is all easy to use. Visit http://www.dovepress.com/ testimonials.php to read real quotes from published authors. 